\title{
Research on Financial Development Opportunity Graph Based on Energy Internet
}

\author{
Dan Wang, ${ }^{\mathrm{a},}$, Yan Chang ${ }^{\mathrm{b}}$, Wenhao Zhu', Qian Zhang ${ }^{\mathrm{d}}$, Shan Jiang ${ }^{\mathrm{e}}$ \\ a State Grid Energy Research Institute, CHINA; wangdan@sgeri.sgcc.com.cn \\ b State Grid Energy Research Institute, CHINA; emily_chang@126.com \\ c State Grid Energy Research Institute, CHINA; Cdream46@163.com \\ ' State Grid Energy Research Institute, CHINA; 17303166@qq.com, \\ ${ }^{e}$ North China Electric Power University, CHINA; khoisme@163.com \\ *Corresponding author
}

\begin{abstract}
Based on the development characteristics of the company's business under the energy Internet, this article evaluates the innovative needs of the energy Internet financial model. A business paradigm for energy internet finance including four key elements of market demand, key resources and core competitiveness, product service design, and profit model has been constructed. Combining the new business and new model of financial innovation needs and advantages of energy and power enterprises, propose a map of opportunities for developing energy Internet financial innovation.
\end{abstract}

Keywords: Energy Internet, Financial Development, Opportunity Map

\section{INTRODUCTION}

With the implementation of the energy Internet strategy and the in-depth development of power grid business, it is of great significance to develop business closely around the power industry chain and the upstream and downstream of the power grid. Through embedded development with the main business of the power grid, we will give full play to the company's financial industry's core hub advantage in the power grid industry chain and promote the clean and low-carbon transformation of the energy industry. It is of great significance to give full play to the function and value of the integration of industry and finance to realize that the financial industry will become stronger and larger while serving the main business and the service industry [1].

\section{ENERGY INTERNET FINANCE DEVELOPMENT CONCEPT AND INNOVATION DEMAND ANALYSIS}

\subsection{The concept of energy internet finance}

"Energy Internet Finance" is a financial ecological model deeply integrated with the ecological development of the energy Internet industry. It is an innovation and upgrade of a single financial product and service model in the traditional energy field [2]. "Energy Internet
Finance" serves the energy Internet platform and the energy Internet industry ecosystem, and realizes the combination of capital flow, information flow, energy flow and customers through the Internet, cloud computing, artificial intelligence, big data, blockchain, Internet of things and other information technologies. A new financial business model integrating financing, payment, investment, consumption and information intermediary will be formed among the multiple entities in the industrial ecosystem [3]. Energy Internet Finance can provide more types, faster and better financial products and services for the development of diversified energy emerging business. Its manifestations are rich and diverse, including but not limited to industry chain finance, energy asset securitization, electronic payment, insurance, funds, trusts, leasing, etc. Based on the concept of traditional energy finance, energy internet finance can be called "energy finance 2.0".

\subsection{Analysis of demand for energy internet finance innovation}

The Energy Internet is a product of the reform of the supply and demand model of the energy industry. The financing problem in traditional energy finance has been given a new form and vitality in the Internet era. The Internet of Energy requires sufficient capital flows and financial tools to create a brand new ecosystem. 
This ecosystem can provide the best financial solutions to achieve optimal aggregation, benign interaction and coordinated development of energy industry capital and financial capital. This requires continuous innovation of the financial model and a new bridge between the energy industry and the financial industry.

\section{ENERGY INTERNET FINANCE CLASSIFICATION}

The development of finance is rooted in the soil of the company's business development [4]. By sorting out financial needs and businesses, we build an embedded development layout. Through extensive interaction between the supply and demand parties, we will jointly explore and create new financial services, new formats and new opportunities, and focus on analyzing the new formats and new business models in the construction of the State Grid Corporation's energy Internet ecosystem, especially the power Internet. Utilize new energy Internet technologies such as Big Cloud Mobile Smart Chain to share the resource value and development results of the energy ecosystem. In addition, by clarifying financial business development demands, improve the capital structure and layout. Sort out the sources of capital that are suitable or available for the business of capital supplementation or structural optimization [5]. The financial business layout is based on the maturity of the company's new business development and can be divided into two types: expansion and deep cultivation, exploration and cultivation.

Expansion and Deep Cultivation: In terms of financial business layout, on the basis of the company's current development of new business models and new models, the company will deploy technology finance, establish service awareness, improve competitiveness, and consolidate and expand market share.

Exploration and Cultivation: Based on the strategic layout of the new business model of the energy industry, a forward-looking financial layout screening mechanism has been established to give play to the guiding role of finance in the industry. At the same time, we will use new technologies such as Big Cloud Mobile Intelligence to form a foundation for customer migration and create an energy internet financial ecosystem.

\section{AN INNOVATION MAP OF ENERGY INTERNET FINANCE BASED ON EXPANSION AND DEEP CULTIVATION}

\subsection{Analysis of financial needs}

Financial services of "Expansion and Deep Cultivation" is based on the company's new business development, and it is necessary to make full use of energy Internet finance to give full play to its advantages, improve competitiveness, and help new businesses continue to consolidate and expand the market. Its financial needs are mainly reflected in the following three aspects: One is to meet the funding needs for the further development of new businesses; The second is to serve the energy Internet industry ecosystem to a greater degree, provide characteristic financial products and services for the grid industry chain and the energy Internet ecosystem, promote clean and low-carbon energy transformation, and drive the upstream and downstream of the industrial chain and the development of the energy industry; The third is to facilitate the development of new businesses to form a new model, through the embedding of energy Internet finance to open up the connection between the $\mathrm{C}$-end and the B-end, and create a new industrial ecology.

\subsection{Key resources and core competitiveness}

Financial services of "Expansion and Deep Cultivation" is based on emerging businesses that have a certain foundation for development and already possesses certain key resources. The first is platform resources. For example, State Grid E-commerce Company (State Grid Financial Technology Group) has established a comprehensive platform covering energy ecommerce and energy financial technology. Relying on the company's unique advantages in public services, resource allocation, technology research and development, etc., it actively promotes e-commerce, Internet finance and other core business development; electric vehicle companies have successfully built a smart car networking cloud platform integrating charging service cloud, travel service cloud, energy service cloud and capability opening platform, connecting $80 \%$ of the public charging piles and more than 40,000 electric vehicles. The second is customer resources. For example, although the company's power equipment manufacturing enterprises face high pressure from market competition, they have a high proportion of key transactions with the main business of the power grid, and the power grid has a significant supporting role, which has realized the diversion of customers from the main power business. The third is data resources. The company possesses massive amounts of data to provide support for the development of emerging businesses. For example, the information and communications industry utilizes core technologies such as "big cloud, mobile intelligence," and other core technologies to develop power big data applications, and achieve rapid development.

\subsection{Product Service Design}

Product service design should closely integrate new business development characteristics and core resource advantages, make full use of new technologies, and realize the deep embedding of energy Internet finance. The first is to develop financial technology, use big data, the Internet and other cores to improve the sharing of main business resources in financial services, 
transform electricity users into financial customers, and provide financial customers with a "precision profile". The second is to develop a comprehensive online financial platform to match the interactive demand platform between investment customers and product suppliers, focusing on the development of energy supply chain finance and energy industry chain consumer finance, and create a win-win energy industry investment and financing service ecosystem. For example, in the photovoltaic cloud network sector, it provides users with a financial service platform for investment and financing services, and introduces photovoltaic property insurance and photovoltaic construction/installation engineering insurance. In the electronic treasure business segment, loan wealth management insurance can be introduced to provide customers with financial service options. The third is a smart service platform. Create a service industry ecosystem and embed financial links. For example, the home care service platform provides meticulous and thoughtful services to meet the needs of the elderly, builds a smart service platform that can be used as a social care service infrastructure in an aging society, and embeds financial functions. The fourth is to develop a functional financial service platform to provide financial support for specific businesses. For example, the development of auto finance provides financial services in the sales and consumption links of the new energy vehicle industry chain for the online and offline sales of new energy vehicles for the Internet of Vehicles. A financial service company that provides nationwide new energy vehicles. Another example is the development of third-party payment, which provides functions such as protocol payment, gateway payment, payment, and refund to businesses such as e-commerce, car networking, and electricity bills.

\subsection{Profit Model}

On the basis of product service design, new business energy Internet finance aggregates traffic through technology platforms to increase the degree of crosspenetration of power users and financial users in various financial product lines. Its profit can come from several types or combinations of platform revenue (commissions and value-added services), industrial innovation, and precise customization. By deeply embedding energy internet finance into emerging businesses, diversified and multi-channel earnings can be achieved (Table 1).

Table 1. The map of energy finance opportunities for Expansion and Deep Cultivation

\begin{tabular}{|c|c|c|}
\hline \multirow{2}{*}{ Occasion } & \multicolumn{2}{|c|}{ Embedded financial business needs } \\
\cline { 2 - 3 } $\begin{array}{c}\text { Internet of vehicles } \\
\text { platform }\end{array}$ & $\begin{array}{c}\text { Stock } \\
\text { Property insurance, industrial funds }\end{array}$ & $\begin{array}{c}\text { Auto finance, auto insurance, } \\
\text { participate in industrial chain } \\
\text { investment }\end{array}$ \\
\hline $\begin{array}{c}\text { E-commerce } \\
\text { platform }\end{array}$ & $\begin{array}{c}\text { Supply chain finance } \\
\text { State grid mall }\end{array}$ & $\begin{array}{c}\text { Supply chain finance, property } \\
\text { insurance }\end{array}$ \\
\hline $\begin{array}{c}\text { Photovoltaic cloud } \\
\text { integrated energy } \\
\text { service }\end{array}$ & $\begin{array}{c}\text { Pledge of income rights, insurance } \\
\text { agency, wealth management and } \\
\text { property insurance }\end{array}$ & $\begin{array}{c}\text { Pledge of income rights, electricity } \\
\text { bill financing }\end{array}$ \\
\hline $\begin{array}{c}\text { Finance lease } \\
\text { Power user portrait }\end{array}$ & $\begin{array}{c}\text { Wealth management, life insurance, } \\
\text { property insurance }\end{array}$ & Trust products \\
\hline
\end{tabular}

\section{AN INNOVATION MAP OF ENERGY INTERNET FINANCE BASED ON EXPLORATION AND CULTIVATION}

\subsection{Financial needs analysis}

In the future, with the advancement of electric energy substitution and the need for the transformation of scientific and technological achievements, the field and scope of the company's services will be further expanded. Such as "two networks" integration of emerging industry clusters, blockchain, multi-site integration, physical asset sharing, data resource development, etc. Finance, as a booster to promote development and take root, can realize planned adjustments, the reasonable allocation of industry-wide production factors, and promote the implementation of new business forms and models.

\subsection{Key resources and core competitiveness}

At present, the company has accumulated some rich experience in the development of deep-growing financial business. The first is the company's current complete financial business system, with resources such as the Yingda Finance Department, e-commerce platform, and electric vehicle platform. The development of the company's financial industry is positioned to "integrate 
industry and finance, and promote production through financing", with the goal of exerting synergy effects, orderly carrying out financial business, and better serving the main business and the real economy. The second is that with the further opening of the electricity market, the grid form has also been connected to a high proportion of new energy sources, the trend of system electronics has changed, the social and economic forms of the Internet economy, digital economy, etc. have changed, and the company's "power supplier" is transformed to an integrated energy service provider. In order to cultivate new profit growth points and new market formats, enhance new customer service capabilities and the company's market competitiveness" concept. The above has ushered in broad development opportunities for financial development, and promoted the innovative development of financial business by realizing the precise connection of supply and demand and the efficient transformation of value. The third is the company/institution with the most patents, such as based on massive full life cycle asset data, user data, and widearea multi-time scale operation data of the power grid. The company has obtained a number of patents in power grid control, power distribution grids, smart distribution transformers, energy systems, and smart inspection robots, and is currently actively implementing it in real application scenarios. Finance can play a major role in the transformation of technological achievements such as patents. While improving business efficiency, it also establishes unique competitiveness for enterprises and creates market barriers. The fourth is to make full use of company data resources. The new generation of people are the "digital natives" who are growing up with the rapid development of digital technology. They prefer to obtain information, consumption, investment and social interaction through the Internet, and expect simple, seamless, personalized and frequent interaction with service providers, from shopping to carpooling. There will be expectations of consumer and financial interaction.

\subsection{Product Service Design}

Through the use of various financial tools, we can realize financial and business integration, improve operational efficiency, reduce transaction costs, cultivate and drive the development of emerging industries and technologies, and stimulate the vitality and creativity of physical enterprises. On the one hand, the development of new business formats requires broadening financing channels. In terms of the company's endogenous capital, we will strengthen the potential of the stock and the quality of growth, improve the profitability of the company by building a flagship, and plan ahead to consider a stable dividend plan for listed companies in the future. In terms of external source replenishment, consider choosing opportunities to implement various financing methods, including but not limited to Tier 1 capital or Tier 2 capital instruments such as common stocks, preferred stocks, perpetual bonds, and Tier 2 capital bonds to form a diversified capital replenishment mechanism and improve the absorptive capacity of capital. On the other hand, it is deeply embedded in the industrial layout. In line with the development strategy of the international leading company's Energy Internet, through the empowerment of technology, create innovative channels, products and models of energy Internet finance, and build a new platform for the development of energy Internet finance. For example, relying on artificial intelligence and sensors to create highly customized financial products in real time; using the opportunity of building smart cities to create new insurance products, leveraging the advancement of "electricity substitution", and realizing the migration of power users to financial users.

\subsection{Analysis of profit model}

Through the in-depth integration of "Energy Internet + Finance + Scenarios", we will expand online finance, smart finance, industry chain finance, and Internet of Things finance, build a financial flagship enterprise, and build a financial business layout system with energy finance characteristics. Utilize a one-stop smart online integrated financial service platform to provide highquality and efficient financial services for enterprises and individuals in the ecosystem such as the main business of the power grid, electricity customers, power equipment and service providers. Through power trading, payment and settlement, capital operation, financing, insurance, asset management services and other links, a financial chain is formed to help the energy Internet ecosystem form a closed loop and realize value realization (Table 2).

Table 2. The map of energy finance opportunities for Exploration and Cultivation

\begin{tabular}{|c|c|c|}
\hline \multirow{2}{*}{ Occasion } & \multicolumn{2}{|c|}{ Embedded financial business needs } \\
\cline { 2 - 3 } & Stock & Increment \\
\hline $\begin{array}{c}\text { "two networks" converge } \\
\text { emerging industry clusters }\end{array}$ & Industry fund & $\begin{array}{c}\text { Strategic investment, consumer finance, } \\
\text { listing }\end{array}$ \\
\hline Blockchain & $\begin{array}{c}\text { Supply chain finance, } \\
\text { trust }\end{array}$ & \begin{tabular}{c} 
Technology finance \\
\hline
\end{tabular} \\
\hline
\end{tabular}




\begin{tabular}{|c|c|c|}
\hline Multi-site integration & Finance lease, trust & Green finance, credit financial products \\
\hline Physical asset sharing & Trust & Resource leasing, strategic investment \\
\hline $\begin{array}{c}\text { Data resource } \\
\text { development }\end{array}$ & Trust, industrial fund & Credit financial products \\
\hline Innovation transformation & Industry fund & $\begin{array}{c}\text { Strategic investments, venture capital } \\
\text { funds, listings, perpetual bonds }\end{array}$ \\
\hline
\end{tabular}

\section{CONCLUSIONS}

Based on the characteristics of energy internet finance, this paper puts forward the concept of energy internet finance and clarifies its basic characteristics. Based on energy Internet financial needs, it is divided into two types: expansion and deep cultivation, exploration and cultivation. Construct a business paradigm of energy financial innovation from the four key elements of market demand, key resources and core competitiveness, product service design, and profit model. The development of energy internet finance deeply integrates internet concepts and innovations with the traditional energy finance industry. This is an emerging financial business model that relies on the energy Internet platform and the energy Internet industry ecosystem; focuses on energy customers; and is deeply integrated into energy with the support of cloud computing, artificial intelligence, big data, blockchain and Internet of Things; integrates financing, payment, investment, consumption and information intermediary.

\section{REFERENCES}

[1] Wu, X.Q. (2002) Bank-Securities Cooperation: China's Financial Trends. China Renmin University Press, Beijing.

[2] Wang, J.P. (2012) Industry Finance Model. Economic Management Press, Beijing.

[3] Bai, W.G., Ma, H.D. (2012) Super industry-finance integration. Yunnan people's Publishing House, Kunming.

[4] Zhang, Y. (2003) Research on the Development Path of Mixed Operation in Financial Industry. China Finance Press, Beijing.

[5] Campbell, M.A., Luce, C.S. (1999) Core competence strategy-a strategy based on core competence. Dongbei University of Finance and Economics Press, Dalian. 